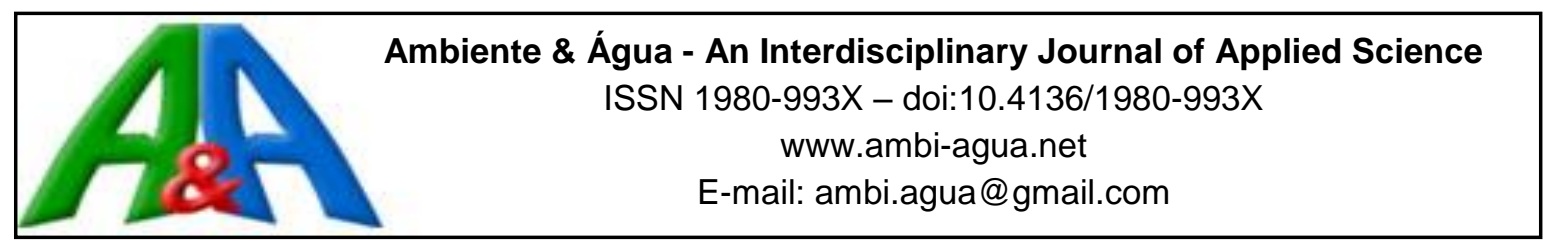

\title{
Environmental services in watersheds with small declivity: fluvial marine plains
}

\author{
ARTICLES doi:10.4136/ambi-agua.2265
}

Received: 03 Apr. 2018; Accepted: 19 Feb. 2019

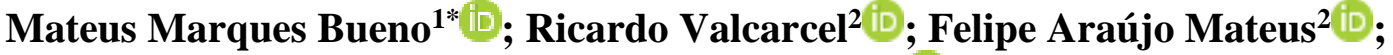 Marcos Gervasio Pereira ${ }^{3}$ (D)}

\author{
${ }^{1}$ Instituto Federal de Educação, Ciência e Tecnologia de Minas Gerais (IFMG), São João Evangelista, MG, Brasil \\ Departamento de Agronomia. E-mail: mateusjuruaia@gmail.com \\ ${ }^{2}$ Universidade Federal Rural do Rio de Janeiro (UFRRJ), Seropédica, RJ, Brasil \\ Instituto de Florestas (IF). Departamento de Ciencias Ambientais (DCA). \\ E-mail: ricardo.valcarcel@gmail.com, felipearaujomateus@gmail.com \\ ${ }^{3}$ Universidade Federal Rural do Rio de Janeiro (UFRRJ), Seropédica, RJ, Brasil \\ Instituto de Agronomia (IA). Departamento de Solos. E-mail: mgervasiopereira01@ gmail.com \\ *Corresponding author
}

\begin{abstract}
Fluvial marine plains harbor environments with reduced declivity, but with different environmental attributes that may be relevant ecosystem services in their watersheds, which can be transformed into opportunities for the development of environmental services payments. This study digitally spatialized part of the ecosystem services related to water availability in the microbasins of the Guandu Basin Hydrographic Basin, the main source of water supply for the metropolitan region of Rio de Janeiro, based on geo-environmental factors and the effects of transposition of watersheds, in order to facilitate the formulation of public policies regarding environmental services. The excerpts with the highest potential for producing environmental services from subsurface water flows, Topographic Wetness Index-ITU (ITU > 11), flat formation and low altimetry $(<40 \mathrm{~m})$, are close to the old silted thalwegs, which can be potentialized by the effects of transposition, notably in the APA Guandu conservation unit. These areas should be prioritized in public and private water systems' preservation programs. The areas near the transposition canals feature environmental services that depend directly on the transposition, and may be subject to management, as found in Guandu conservation unit. Flat areas with $(7<$ ITU $<11)$ have their ecosystem services transferred from subsurface water flows to surface water flows and are dependent more on meteorological phenomena and on ways to manage heavy rain showers through their use, especially as altimetry and slope increase.
\end{abstract}

Keywords: hydrogenetic areas, topographical index of wetness, water management.

\section{Serviços ambientais em microbacias com baixa declividade: planícies fluvio-marinhas}

\section{RESUMO}

Planícies fluvio-marinhas abrigam ambientes com reduzida declividade, porém com ofertas diferenciadas de atributos ambientais que podem constituir relevantes serviços 
ecossistêmicos nas suas bacias hidrográficas, que podem ser transformadas em oportunidades para o desenvolvimento de pagamento de serviços ambientais. $\mathrm{O}$ estudo espacializou parte dos serviços ecossistêmicos relacionados a disponibilidade hídrica nas microbacias da Bacia Hidrográfica do Sistema Guandu, principal manancial de abastecimento da região metropolitana do Rio de Janeiro, com base em fatores geo-ambientais e efeitos de transposição de água entre bacias hidrográficas, a fim de facilitar a tomada de decisão das políticas públicas em relação aos serviços ambientais. Os trechos com maior potencial para a produção de serviços ambientais a partir de vazões subterrâneas, índice de umidade topográfica - ITU (ITU >11), formação plana e baixa altimetria $(<40 \mathrm{~m})$, estão próximo aos antigos talvegues assoreados, que podem ser potencializados pelos efeitos da transposição, notadamente na unidade de conservação APA Guandu. Áreas planas com ( 7 < UIT < 11) têm seus serviços ecossistêmicos transferidos dos fluxos de água sub-superficiais para os fluxos de águas superficiais e dependem mais dos fenômenos meteorológicos e das formas de manejo de chuvas intensas durante seu uso, especialmente quando a altimetria e inclinação aumentam.

Palavras-chave: áreas hidrogenéticas, índice topográfico de umidade, manejo hídrico.

\section{INTRODUCTION}

The region of fluvial marine plains in Sepetiba Rio de Janeiro, as with others along the Brazilian coastline, present environmental services related to water resources differently, because the variables of terrain, soil, climate, anthropogenic interventions and mountain ranges' influence allow the production and storage of water in the soil, altering the supply of this resource in drainage areas throughout the watershed.

In this way, Meireles and Campos (2010) studied different coastal regions, and affirm that there may be differentiation in the production capacity of ecosystem services. This differentiation in the production of water resource is caused by the variation of the constituents of the sediments that make up the plains, rainfall distribution and local relief (Costanza et al., 1997). In addition, intensive and irregular soils use and recent climate changes, such as the increase in temperature and irregular distribution of rainfall, demand more efficient alternatives in the management of water resources in these places where there is already ample water availability.

Geoprocessing techniques, linked to environmental analyses, and the correct interpretation of the processes that occur in watersheds, allow the identification of hydrologically sensitive areas, leading to the knowledge of their aptitudes and potential. Therefore, with the technological advances of recent decades, the computerization of data is important to the work in environmental science, seeking to optimize from the planning stage to the processing and interpretation of data.

There is therefore a close relationship between technological development, the identification of ecosystem services and the sustainable development of a region (Tacconi, 2012). Thus, it is important to identify how contemporary geomorphological processes are working and how they will intervene in the future; this knowledge is essential for designing environmental policies based on the ecosystem, such as payment programs for environmental services (Gjorup et al., 2016).

For that reason, the identification of natural ecosystem services will only be possible when human demands and planning tools to identify and spatialize areas to receive environmental services measures in a watershed are combined. The small watershed that composes the Guandu System is very important to the water supply of Rio de Janeiro. Therefore, this study used digital processing to infer ecosystem services that can be transformed at environmental service in the Guandu System.

Rev. Ambient. Água vol. 14 n. 3, e2265 - Taubaté 2019 


\section{METHODS AND MATERIAL}

\subsection{Characterization of the Fluvial Marine Plains Studied}

The studied region comprises the Guandu Watershed System (BHSG), where one of several Brazilian fluvial marine plains is located. This watershed is of fundamental importance for the water supply of the city of Rio de Janeiro. Currently, Guandu channel is source of water for human use and for various productive sectors such as the steel industry, petrochemicals, food and beverages, clothing, among others. The total area of BHSG is $1,437.59 \mathrm{~km}^{2}$. Considering Lajes' riverside as the main segment of the system, the total length of the Guandu River is $108.5 \mathrm{~km}$.

The predominant climate in the region is the Köppen Aw. The rainfall regime is characterized by a rainy season, from December to March (summer), and dry season, from June to August (winter). The annual average rainfall is $1,270 \mathrm{~mm}$, according to data from the meteorological station historical series A601-Agricultural Ecology, located in the city of Seropédica-RJ. However, there is no uniformity in the regime of rainfall along the watershed, which is related to the irregularity of the atmospheric systems. It causes a variation in the total volume of precipitation from 700 to $2,400 \mathrm{~mm}$ per year.

Sepetiba Bay Watershed's lithological units occur generally disseminated among themselves, Proterozoic age lithologies show clear structural direction NE-SW and Neogenous sediments scattered throughout the low formation points. Some units occur in isolation, especially the units of Cenozoic age, and some of Proterozoic age. The fluvial marine sediments of Neogenous age are spread along low areas and around elevations composed by Proterozoic rocks, forming Fluvial Marine Plains (Garcia et al., 2015).

According to a survey conducted by Santos et al. (2013), adapted on Figure 1, the lower parts of the watershed and near the coast (upwelling zone) are composed by Ultisols (Albaquults) and represent $33.92 \%$ of the watershed's total area. In addition, the Ultisols dominate almost the entire remainder of the watershed, or $63.45 \%$.

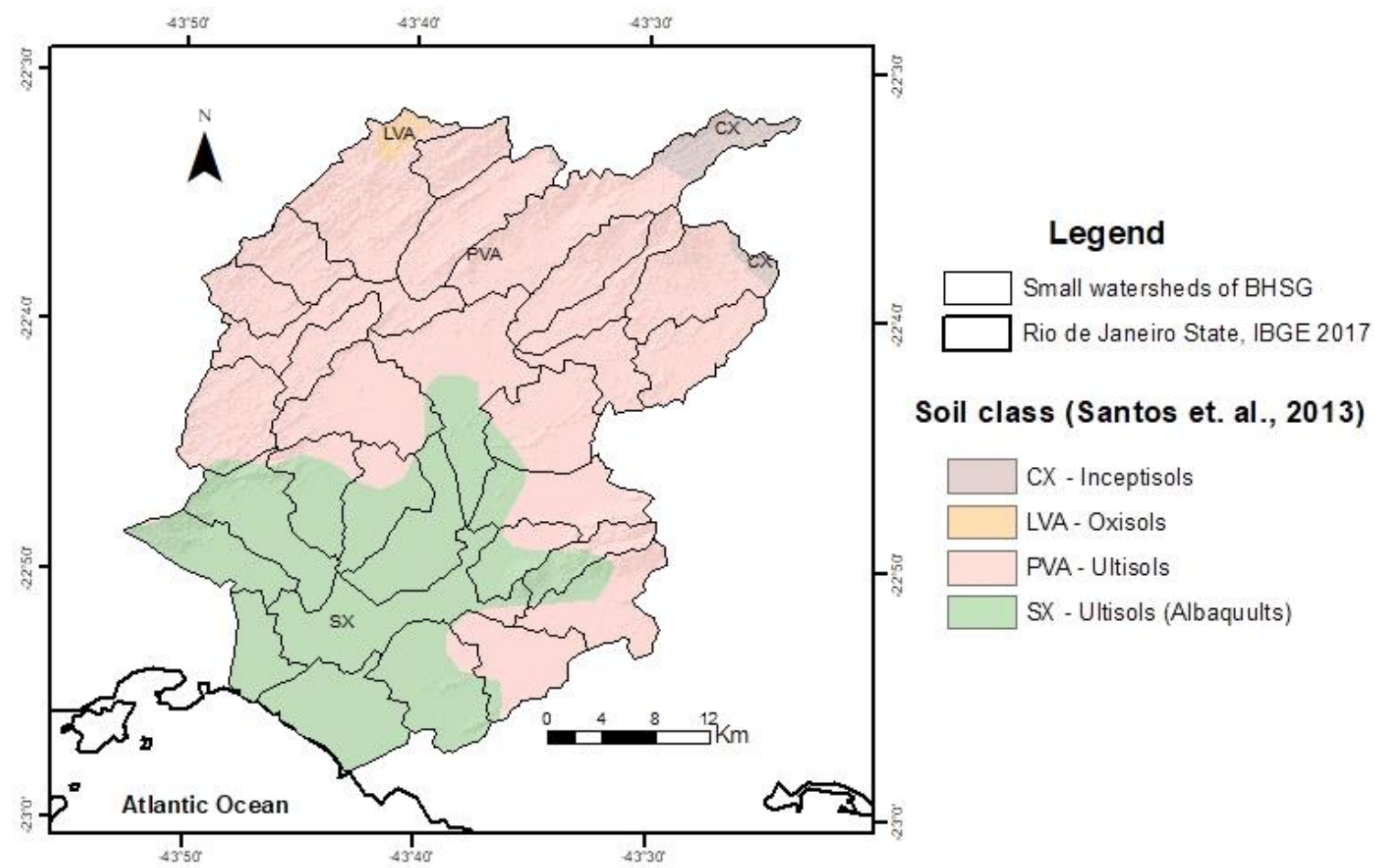

Figure 1. Soil classes for the Guandu Watershed System (BHSG), adapted by Santos et al. (2013). 


\subsection{BHSG's Morphometric Characterization}

The Digital Model of Hydrologically Consistent Elevation (MDE-HC) of the area was obtained by processing the cartographic database from the Brazilian Institute of Geography and Statistics (IBGE), with contour levels offsets of $10 \mathrm{~m}$, hydrography and quoted points, on a scale of 1:25,000. The interpolation of elevation's data was performed with spatial resolution of $10 \mathrm{~m}$, via the Software ArcGIS 10.2.1, using the spatial analysis tool. From the MDE-HC were obtained altimetry classes (reclassify tool), slope (surface and slope tools), aspect (surface and aspect tools), and curvature surfaces (surface and curvature tools).

The physical parameters of the BHSG of all small watersheds (area, perimeter, channels' lengths, drainage density, form factor, index of circularity [Ke], compactness index [Kc], and sinuosity index [Is]) were computed as described by the methodology of Hajam et al. (2013), using the MDE-HC and the limits provided by the hydrographic basin tool from the ArcGIS. These parameters Ke, Kc and Is, are important to compare different watersheds. Using area, perimeter and length it is possible to create a standardization and compare the characteristics of the watershed with standard forms and with one another.

Drainage obtained by automatic interpolation of MDE-HC, was compared with the official IBGE and overlapped to high-resolution satellite imagery from Landsat 5 TM satellite, 2006, acquired from the National Space Research Institute (INPE)'s database website.

\subsection{Floodplain and Water Dynamics}

The automatic delimitation refers to the detection of floodplains through the classification of a regional (not local) topographic variable, recognized as an indicator, by means of the Topographic Wetness Index (ITU). The methodology consisted in obtaining regional topographic variables from the MDE-HC, based on the developments of the ITU. The data processing was carried out by SAGA GIS 2.1.2 software. The UTI characterizes the surface water saturation zones and the water content in the soils. (Prates et al., 2012) found that for well-drained soils, the index varies between 4 and 5, in moderately drained soils it varies between 5 and 7 and in poorly drained soils, the indices oscillate between 7 and 12. This index can also be associated with soil thickness, structural grade and permeability (Lin et al., 2006).

The local water dynamics was characterized from the regional rainfall, with data obtained directly from INMET's conventional and automatic stations. The anthropized micro watersheds' water dynamics was determined by the characterization of contemporary geomorphological processes, simplified in hydrogenetic zones (Table 1).

Table 1. Parameters used to classify the hydrogenetic zones of Guandu's Hydrographic Watershed System (BHSG).

\begin{tabular}{ll}
\hline Hydrogenetic zones & Description \\
\hline \multirow{2}{*}{ Capitation } & $\begin{array}{l}\text { Areas with high elevations (reference to the lowest elevation of the watershed). } \\
\text { This areas start from the top of the watershed, with small and varying angular } \\
\text { inclination, deeper soils, infiltration prevail and subsurface flow. }\end{array}$ \\
\hline \multirow{3}{*}{ Transition } & $\begin{array}{l}\text { Areas with intermediate elevations and high slope. Shallow soils with frequent } \\
\text { processes of surface layer movement. Region favorable to the occurrence of } \\
\text { surface runoff and mass displacement processes. }\end{array}$ \\
\hline \multirow{3}{*}{ Outcrop } & $\begin{array}{l}\text { Areas of lower relative elevation and low slope. Region of sediment } \\
\text { accumulation, with presence of soils with greater water storage capacity. } \\
\text { Prevalence of subsurface flow processes. }\end{array}$ \\
\hline
\end{tabular}

Finally, the interference of the construction of Guandu's canal and other drainages in the region were compared with the identified plains, in order to infer about their interference in the availability of the watershed's environmental services. The checking of the results was made

Rev. Ambient. Água vol. 14 n. 3, e2265 - Taubaté 2019 
using high-resolution satellite imagery from Landsat 5 TM satellite, 2006; in addition to the historical series of images available on Google Earth Pro program for the years 2002 to 2016. The processing of maps and images was performed in ArcGIS 10.2.1.

\section{RESULTS AND DISCUSSION}

The small watersheds (MB1 to MB33 - less MB 18 e MB 19) and the topography classes can be seen in Figure 2. The physical indexes of BHSG (Table 2) indicate a variation, since the $\mathrm{Ke}$ and $\mathrm{Kc}$ values point to the presence of more rounded forms in the central south region and more elongated forms in the surroundings. Similarly to what was verified by analyses of Dd and Is indexes, showing that the small surrounding watersheds are more drained (values above average, 2.26) and with sinuosity index further from the unit. Ferrari et al. (2013) indicated that the more elongated and the more efficient the drainage conditions are, the more likely is water loss through the watershed's outflow.

In the area, the geological and climatic conditioners markedly influenced the effects of geomorphological factors, allowing formation of sites with high climate variation. This variability causes differences in the provision of environmental services available in small BHSG, noted in the variability observed in values of obtained for the ITU (Figure 3), which occur preferentially in non-consolidated sand, gravel, silt, clay and peat deposits.

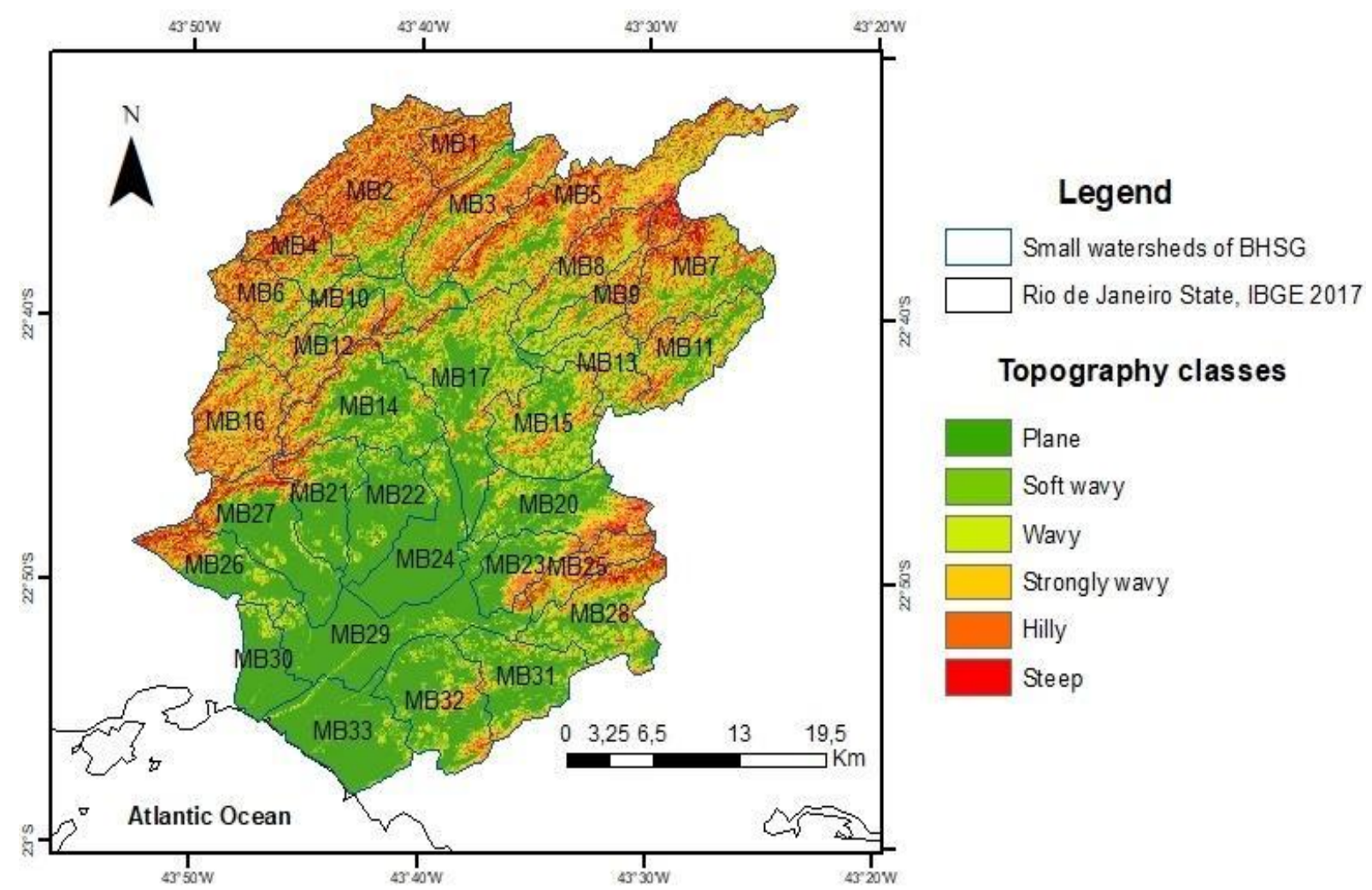

Figure 2. Topographic classes and small watersheds of the Guandu Watershed System (BHSG). 
Table 2. Physical Parameters of Guandu's Hydrographic Watershed System (BHSG).

\begin{tabular}{|c|c|c|c|c|c|c|c|c|c|}
\hline \multirow{2}{*}{ Item } & $\mathbf{A}$ & $\mathbf{P}$ & $\sum \mathbf{L}$ & $\mathbf{L}$ & $\mathbf{L}$ & Dd & Ke & $\mathrm{KC}$ & Is \\
\hline & $\mathrm{km}^{2}$ & \multicolumn{2}{|c|}{$\mathrm{km}$} & \multicolumn{2}{|c|}{ M } & $\mathrm{m} / \mathrm{m}^{2}$ & - & - & $\mathrm{m} / \mathrm{m}$ \\
\hline BHSG & $1,437.59$ & $1,177.77$ & $3,034.50$ & $75,584.85$ & $58,439.59$ & 2.11 & 0.01 & 8.70 & 1.29 \\
\hline MB1 & 24.98 & 22.69 & 57.26 & $12,096.05$ & $2,763.63$ & 2.29 & 0.61 & 1.27 & 1.38 \\
\hline MB2 & 80.60 & 47.45 & 182.82 & $18,546.54$ & $12,990.15$ & 2.27 & 0.45 & 1.48 & 1.43 \\
\hline MB3 & 55.38 & 38.38 & 124.63 & $14,394.31$ & $12,990.19$ & 2.25 & 0.47 & 1.44 & 1.11 \\
\hline MB4 & 31.16 & 27.69 & 70.02 & $9,058.68$ & $6,287.42$ & 2.25 & 0.51 & 1.39 & 1.44 \\
\hline MB5 & 97.62 & 73.40 & 231.78 & $32,277.88$ & $27,662.56$ & 2.37 & 0.23 & 2.08 & 1.17 \\
\hline MB6 & 25.85 & 23.66 & 57.62 & $8,418.06$ & $5,795.10$ & 2.23 & 0.58 & 1.30 & 1.45 \\
\hline MB7 & 55.66 & 37.51 & 146.30 & $12,141.25$ & $6,287.42$ & 2.63 & 0.50 & 1.41 & 1.93 \\
\hline MB8 & 36.96 & 33.49 & 95.10 & $16,378.08$ & $13,779.65$ & 2.57 & 0.41 & 1.54 & 1.19 \\
\hline MB9 & 29.79 & 37.33 & 74.31 & $17,519.94$ & $15,084.21$ & 2.49 & 0.27 & 1.91 & 1.16 \\
\hline MB10 & 43.50 & 58.38 & 108.79 & $20,100.51$ & $16,042.07$ & 2.50 & 0.16 & 2.48 & 1.25 \\
\hline MB11 & 40.68 & 34.09 & 92.44 & $13,998.92$ & $11,730.74$ & 2.27 & 0.44 & 1.50 & 1.19 \\
\hline MB12 & 24.13 & 28.38 & 56.69 & $12,027.80$ & $9,919.56$ & 2.35 & 0.38 & 1.62 & 1.21 \\
\hline MB13 & 29.23 & 36.15 & 70.06 & $7,829.59$ & $6,294.58$ & 2.40 & 0.28 & 1.87 & 1.24 \\
\hline MB14 & 61.21 & 39.57 & 140.10 & $14,572.89$ & $11,441.41$ & 2.29 & 0.49 & 1.42 & 1.27 \\
\hline MB15 & 52.94 & 34.02 & 116.64 & $10,195.36$ & $9,394.11$ & 2.20 & 0.57 & 1.31 & 1.09 \\
\hline MB16 & 47.44 & 28.75 & 115.33 & $11,436.97$ & $9,167.53$ & 2.43 & 0.72 & 1.17 & 1.25 \\
\hline MB17 & 85.01 & 61.37 & 198.30 & $20,652.88$ & $16,280.15$ & 2.33 & 0.28 & 1.86 & 1.27 \\
\hline MB20 & 50.06 & 41.27 & 115.55 & $17,178.21$ & $13,590.73$ & 2.31 & 0.37 & 1.63 & 1.26 \\
\hline MB21 & 38.03 & 31.52 & 82.35 & $9,770.26$ & $9,047.23$ & 2.17 & 0.48 & 1.43 & 1.08 \\
\hline MB22 & 39.36 & 32.02 & 87.02 & $8,813.97$ & $7,630.04$ & 2.21 & 0.48 & 1.43 & 1.16 \\
\hline MB23 & 26.05 & 24.49 & 55.57 & $8,636.09$ & $7,382.69$ & 2.13 & 0.55 & 1.34 & 1.17 \\
\hline MB24 & 48.01 & 39.31 & 84.55 & $15,657.08$ & $12,654.35$ & 1.76 & 0.39 & 1.59 & 1.24 \\
\hline MB25 & 22.75 & 28.17 & 48.41 & $11,628.15$ & $10,023.34$ & 2.13 & 0.36 & 1.65 & 1.16 \\
\hline MB26 & 37.82 & 34.30 & 89.80 & $13,017.75$ & $12,265.06$ & 2.37 & 0.40 & 1.56 & 1.06 \\
\hline MB27 & 53.08 & 43.02 & 130.23 & $14,513.62$ & $11,668.40$ & 2.45 & 0.36 & 1.65 & 1.24 \\
\hline MB28 & 48.53 & 40.09 & 103.68 & $13,132.87$ & $11,021.79$ & 2.14 & 0.38 & 1.61 & 1.19 \\
\hline MB29 & 72.87 & 70.59 & 169.50 & $15,216.71$ & $14,738.26$ & 2.33 & 0.18 & 2.32 & 1.03 \\
\hline MB30 & 26.17 & 25.81 & 45.69 & $5,742.56$ & $5,142.08$ & 1.75 & 0.49 & 1.41 & 1.12 \\
\hline MB31 & 42.39 & 33.59 & 92.29 & $9,686.88$ & $8,811.01$ & 2.18 & 0.47 & 1.44 & 1.10 \\
\hline MB32 & 55.81 & 34.66 & 112.79 & $11,144.91$ & $7,727.16$ & 2.02 & 0.58 & 1.30 & 1.44 \\
\hline MB33 & 54.52 & 36.63 & 110.73 & $12,631.90$ & $6,815.07$ & 2.03 & 0.51 & 1.39 & 1.85 \\
\hline
\end{tabular}

Legend: A - hydrographical watershed area; P - perimeter of the hydrographical watershed area; A - watershed area; $\sum \mathrm{L}$ - length of all watershed drains; L - length of the main drain of the watershed; 1 - vectorial length of watershed' main drain; DD - drainage density; Ke - circularity index; KC - compactness index; Is - sinuosity index; BHSG Guandu Watershed System and M1 to M33 - small watershed of the BHSG.

About $50 \%\left(720.81 \mathrm{~km}^{2}\right)$ of the area of BHSG is less than $40 \mathrm{~m}$ in altitude and $36 \%$ $\left(511.49 \mathrm{~km}^{2}\right)$ presents a flat surface (Figure 1). These areas are located in the central region of the watershed, where $91.21 \mathrm{~km}^{2}$ presents ITU above 11 units; they are humid plains, with maximum expression of natural ecosystem services. Immediately adjacent to these areas, there are saturated areas with less intensity, with ITU values of between 5 to 11 units, totaling $580.97 \mathrm{~km}^{2}, 40.41 \%$ of the BHSG's total area. The surface in this area is characterized as soft wavy, wavy and strong wavy. The driest areas represent $53.24 \%\left(765.40 \mathrm{~km}^{2}\right)$ and are located in peripheral areas that are not in contact with the sea. The surface is predominantly mountainous and rugged in small portions. 


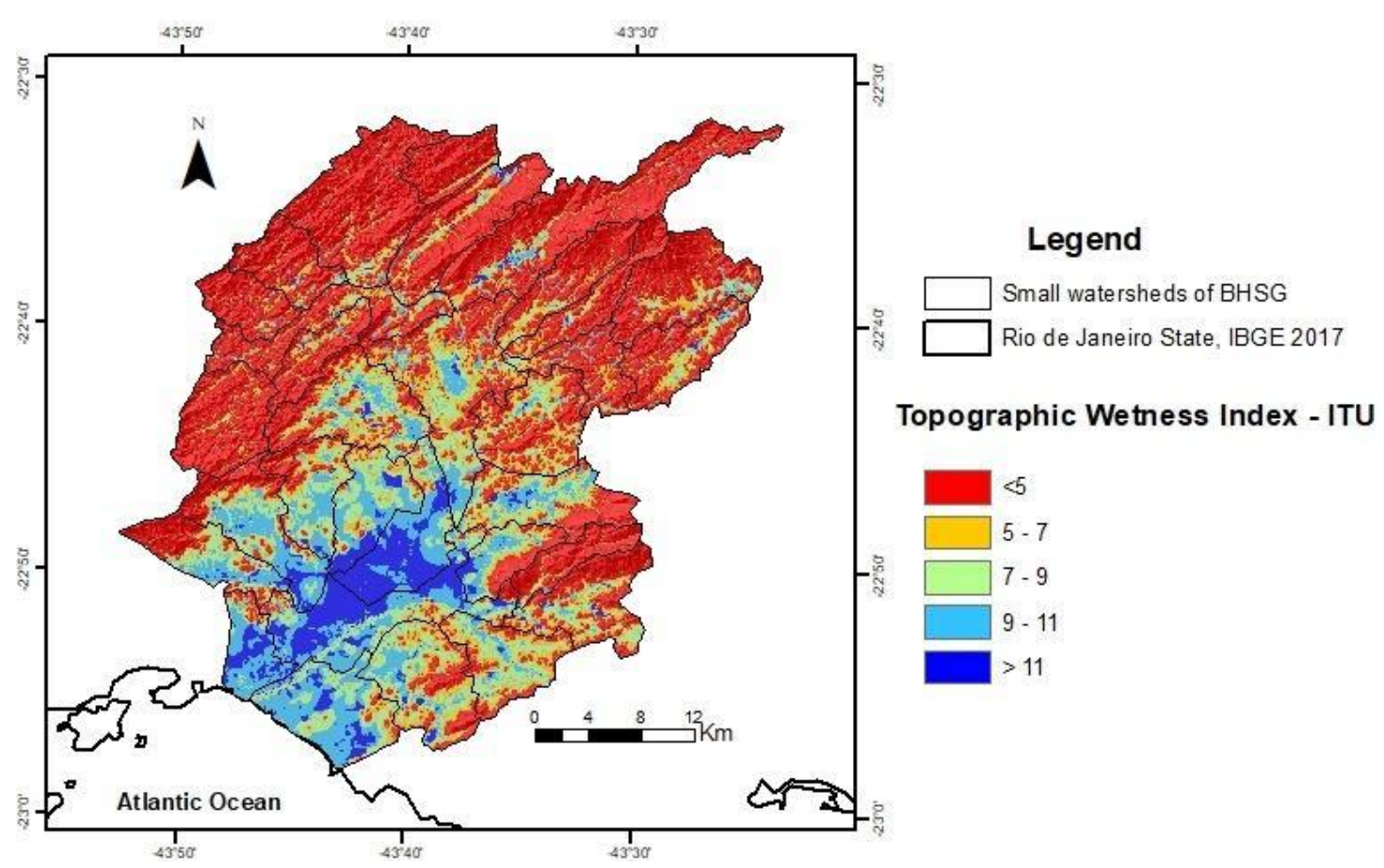

Figure 3. Topographic Wetness Index (ITU), to the watershed of the Guandu System (BHSG).

The soil distribution indicates the prevalence of Ultisols (Albaquults) in low areas and in part of the transitional areas. The other areas feature mostly Ultisols in the transition areas and with rugged relief. Oxisols and Inceptisols are evidenced in areas with greater altimetry and irregular topography, and represent less than $3 \%$ of the total area of the watershed.

The Ultisols (Albaquults), for having a low amount of clay on the surface, have less surface water storage capacity (Dondeyne et al., 2014). In this way, the water flow is influenced by other factors, mainly by relief and the upstream and downstream hydraulic potential. The predominance of Ultisols (Albaquults) in the flat regions, where there was the deposition in the channels that drain to the sea, with low hydraulic gradient, indicating selective sedimentation, with coarse sediments in high and fine parts in low. In the transition to the mountains, there are some areas of low elevation (about $40 \mathrm{~m}$ ). These area are slightly undulate to undulate hills, shaped as a "half orange". This configuration shows the differentiation of storage and water flow capacities in the watershed, as well as the distribution of morphological features.

Reis et al. (2014) by studying the effect of different uses on Ultisols (Albaquults), found that the formation and stabilization of aggregates occur simultaneously with the influence of physical, chemical and biological processes in the soil. These aggregates, which are agents of soil structuring, store water and are predominated by horizontal flows of water. The influence of the salinas wedges occur in the opposite direction, often in the mains canal (paleo channels). Salamene et al. (2011) studied this areas and found influence of the sea water for $20 \mathrm{~km}$ in the main Guandu channel.

It is important to point out that the land use promotes changes in the land's physical attributes, mainly in soil structure, which may promote or hinder the water storage in the soil (Ortigara et al., 2014). Intensive cultivation, without the development of conservation practices, for several years, as occurred in the transitional region, can degrade the soil, altering its water retention.

The river influence on soil's water storage of fluvial marine plains is related to the peculiarities of these sites and their management. When there is an imbalance generated by changes in land use or even by periods of restriction, the influence of the sea can prevail. On the other hand, in the case of preservation and climate normality, the greatest influence is given by rainwater. 
The relationship between the ITU and the soil's water pressure is positive and is variable in time and space for a natural forest catchment watershed (Liang and Chan, 2017). In this way, ITU can be correlated with depth and capacity of the soil to keep water over time. A similar assessment, but in agricultural soils, performed by Buchanan et al. (2014) demonstrated that the ITU can be correlated with superficial and deep soil wetness segments and can coexist.

The wetness areas operate hydrologically in a harmonious way with the transitional areas, working as the great aquifers that reach the surface of the flood plain's soil. These areas when saturated extend laterally. As observed by Baptista et al. (2014), in their study in areas of an old paleo canal (thalwegs) embedded by sediments of fluvial influence, the current and former sites of sand accumulation are present in the plains and exhibit a particle size stratification, which is related to the distance from the source of emission and the reduction of transport energy. This evidence refers to the geomorphological role of the basins in the formation of fluvial-marine plains near the coast, where we developed the study. The ecosystem services prevalent in wet areas arise from the impoundment of the sub surface and deep streams, depending on the influence of tidal oscillations. In the part closest to the sea, there is an interdependence of the effects of saline intrusion, which causes a high degree of salinity up to $8 \mathrm{~km}$ on the river surface and is introduced to the interior of the continent by the lines of drainage channels (Salamene et al., 2011).

These factors show that there is a wide variation in the dynamics of this system, and confirm that in the flat area there is a strong influence of the water table in the water control system of the watershed, which gives these areas a predominance of vertical and horizontal movements of subsurface water. In the mountainous areas, there is a predominance of horizontal and vertical movements on the surface, and both are found in the areas of transmission.

In this sense, the slope is the expression of the mass movement potential, water flow velocity and other erosion processes (Pinheiro et al., 2012), and determines the amount of water a soil can hold, the potential for erosion or deposition, among other fundamental processes (Wilson and Gallant, 2000). In this way, it can be verified that most of the area has its natural potential reduced due to erosion processes.

Similarly, curvature, plan and profile data aid in the interpretation of morphological characteristics of landscape such as susceptibility to erosion, surface runoff, storage and flow of water. In the BHSG, three different hydrogenetic zones were identified: Outcrop, Transition and Capitation (Figure 4). In the Outcrop zone, there is a predominance of a plane topographic profile followed by the convex form. in the transition zone also there is a predominance of the convex form, but with soft wavy, wavy and strongly wavy reliefs. The Capitation zone represents small areas in this watershed, so the hydric dynamic is more important for the two other zones.

These indicators show that there is a differentiation in dynamics of water flows along the watershed; in the upwelling area horizontal flows predominate and in transmission areas there is the interference of horizontal and vertical streams. This pattern shows that there is a differentiation of environmental service capacity in these areas.

On the other hand, orientation of the relief is important because it allows the visualization of the face of sun exposure, thus making it possible to infer about the local micro-climate (temperature, precipitation and humidity), and about the differentiation of the evapotranspiration process of the areas (Valeriano, 2003). The BHSG presents only a slight northern predominance (about 28\%); other orientations are distributed evenly. Little variation indicates that there is homogeneity with respect to sun exposure and, consequently with respect to the ability of wetness loss. However, the evaluation of this parameter to specific watersheds shows differences in exposure and, as a result, in the water production capacity.

Rev. Ambient. Água vol. 14 n. 3, e2265 - Taubaté 2019 


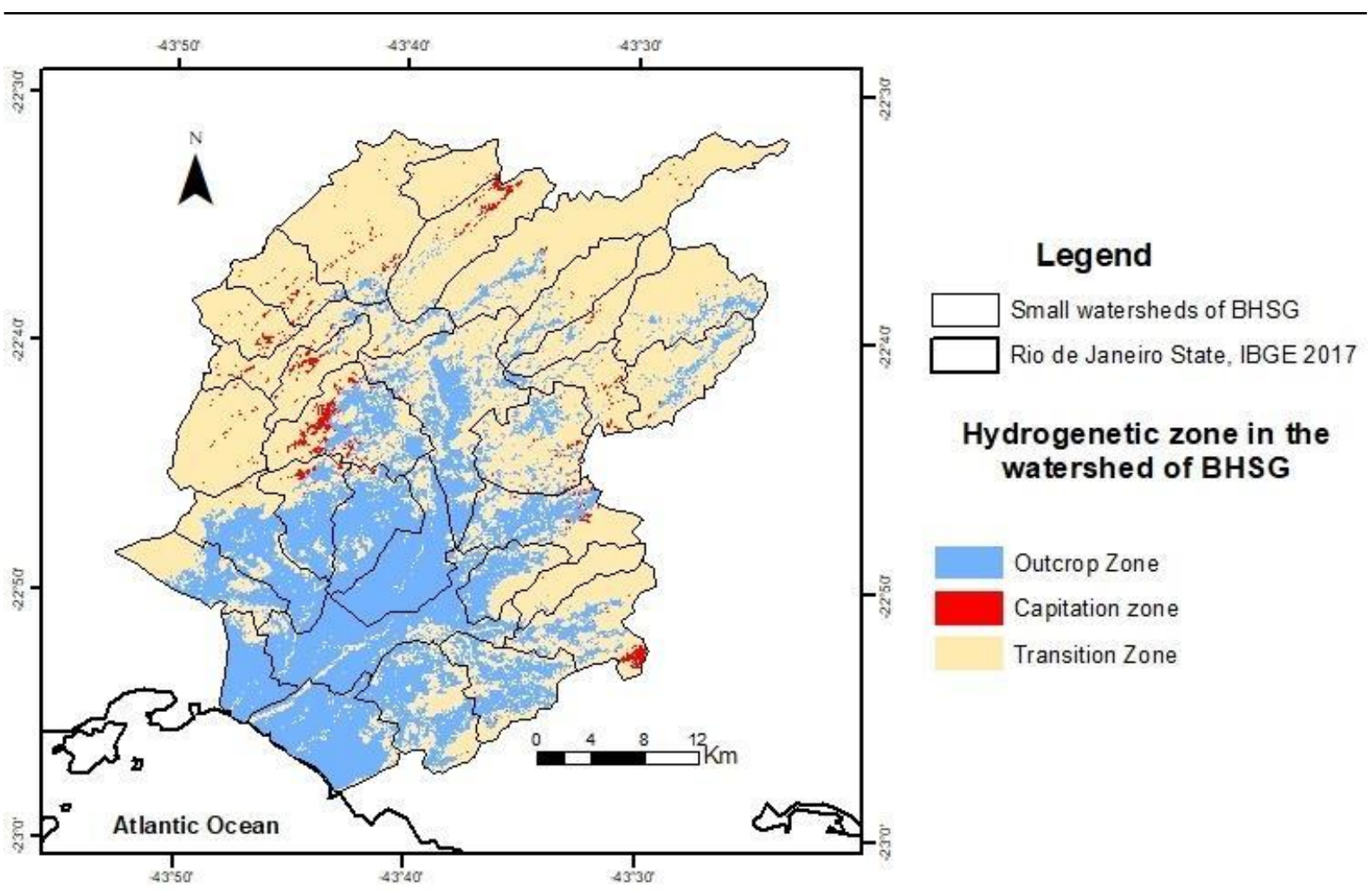

Figure 4. Hydrogenetic zone of the watershed of the Guandu System (BHSG).

Salamene et al. (2011) studied the Guandu channel gutter and its interaction with a buffer of $100 \mathrm{~m}$ across the central line. This paper shows that after the construction of the artificial canal in the BHSG, there was a lowering of the water table. This alteration led to the increase of the area of outcropping upstream and the decrease of the area downstream. Consequently, there was a change in the local water dynamics, causing the regulatory areas to change. The impact of this alteration should be taken into account in public policies related to Guandu's protection area, since the preservation of this resource is of fundamental importance to government policies.

\section{CONCLUSIONS}

The variation in precipitation constitutes an important factor for the planning in the small watersheds; however, the constant inward flow of $160 \mathrm{~m}^{3} \mathrm{~s}^{-1}$ transposition that encompasses the BHSG in terms of environmental services made the storage areas in the water table more important. The morphological characterization and development of the ITU allowed for the segregation areas that serve as supply and catchment areas and of the floodplain system. These areas are located mainly in the surrounding areas of the ancient beds of natural paleo channels, traversed by Guandu's canal, both upstream and downstream, and should be prioritized in public and private water system preservation programs. In the areas occupied by the floodplain, the ITU has enabled the identification of differentiated areas regarding water production.

The Guandu's canal passage through the areas of floodplain influence affects positively the upwelling areas upstream. On the contrary, downstream a modification can be perceived in order to decrease the water flow and cause a deficit, mainly from the demotion of the water table and the modification in the drainage system. In areas above the elevation of $40 \mathrm{~m}$, the effects of the floodplain and transposing channel are barely noted. The micro-watersheds located in these areas need to be hydrologically determined; that is, they depend on rain and on the system's water storage and output. 
The inability of water supply to meet the growing demand in the metropolitan region of Rio de Janeiro highlights the need for alternative management strategies of the BHSG. Among them, we highlight the renaturalization on the outcrop zone functions, in order to take advantage of water storage capacity during the full season so that it may be utilized during the dry season.

\section{ACKNOWLEDGEMENTS}

We thank the Federal Rural University of Rio de Janeiro, specifically the PPGCAF, LMBH and LGCS. We recognize CNPq and the Petra Agregados mining company for the financial support.

\section{REFERENCES}

BAPTISTA, M. N.; VALCARCEL, R.; MAYA, V.; CANTO, F. Selection of Preferred Floodplains for the Renaturalization of Hydrologic Functions: A Case Study of the Paraíba do Sul River Basin, Brazil. Water resources management, v. 28, n. 13, p. 47814793, 2014. https://doi.org/10.1007/s11269-014-0775-z

BUCHANAN, B. P.; FLEMING, M.; SCHNEIDER, R. L.; RICHARDS, B. K.; ARCHIBALD, J.; QIU, Z.; WALTER, M. T. Evaluating topographic wetness indices across central New York agricultural landscapes. Hydrology and Earth System Sciences, v. 18, n. 8, p. 3279, 2014. https://dx.doi.org/10.5194/hess-18-3279-2014

COSTANZA, R.; D’ARGE, R.; DE GROOT, R.; FARBER, S.; GRASSO, M.; HANNON, B.; RASKIN, R. G. The Value of the World's Ecosystem Services and Natural Capital. Nature, v. 387, p. 253-260, 1997. https://doi.org/10.1038/387253a0

DONDEYNE, S.; VANIERSCHOT, L.; LANGOHR, R.; VAN RANST, E.; DECKERS, J. The Soil Map of the Flemish Region Converted to the 3rd Edition of the World Reference Base for Soil Resources. Brussels: Departement Leefmilieu, Natuur \& Energie, 2014.

FERRARI, J. L.; SILVA, S. F.; SANTOS, A. R.; GARCIA, R. F. Análise morfométrica da subbacia hidrográfica do córrego Horizonte Alegre, ES. Revista Brasileira de Ciências Agrárias, v. 8, n. 2, p. 181-188, 2013. https://dx.doi.org/10.5039/agraria.v8i2a1575

GARCIA, M. G. M.; BRILHA, J.; LIMA, F. F.; VARGAS, J. C.; AGUILAR, A. P.; DULEBA, W.; FERNANDES, L. A.; FIERZ, M.; MARTINS, L.; RAPOSO, M. I. B.; RICARDIBRANCO, F.; ROSS, J.; SALLUN, W. The inventory of geological heritage of the State of São Paulo, Brazil: methodological basis and preliminary results. In: INTERNATIONAL SYMPOSIUM OF PROGEO, 8., 2015, Reyjavik, IS. Anais[...] Uppsala: Progeo, 2015. p. 32-33.

GJORUP, A. F.; FIDAlGO, E. C. C.; PRADO, R. B.; SCHUlER, A. E. Análise de procedimentos para seleção de áreas prioritárias em programas de pagamento por serviços ambientais hídricos. Revista Ambiente \& Água, v. 11, n. 1, p. 225, 2016. https://dx.doi.org/10.4136/ambi-agua.1782

HAJAM, R. A.; HAMID, A.; BHAT, S. Application of morphometric analysis for geohydrological studies using geo-spatial technology - A case study of Vishav drainage watershed. Hydrology Current Research, v. 4, n. 3, p. 1-12, 2013. 
LIANG, W. L.; CHAN, M. C. Spatial and temporal variations in the effects of soil depth and topographic wetness index of bedrock topography on subsurface saturation generation in a steep natural forested headwater catchment. Journal of Hydrology, v. 546, p. 405-418, 2017. https://doi.org/10.1016/j.jhydrol.2017.01.033

LIN, H. S.; KOGELMANN, W.; WALKER, C.; BRUNS, M. A. Soil moisture patterns in a forested catchment: A hydropedological perspective. Geoderma, v. 131, p. 345-368, 2006. https://doi.org/10.1016/j.geoderma.2005.03.013

MEIRELES, A. J. A.; CAMPOS, A. A. Componentes Geomorfológicos, Funções e Serviços Ambientais de Complexos Estuarinos no Nordeste do Brasil. Revista da ANPEGE, v. 6, n. 6, p. 89-107, 2010. https://doi.org/10.5418/RA2010.0606.000

ORTIGARA, C.; KOPPE, E.; LUZ, F. B.; BERTOLLO, A. M.; KAISER, D. R.; SILVA, V. R. Uso do solo e propriedades físico-mecânicas de Latossolo Vermelho. Revista Brasileira de Ciência do Solo, v. 38, n. 2, p. 619-626, 2014.

PINHEIRO, H. S. K.; DA SILVA CHAGAS, C.; DE CARVALHO JÚNIOR, W.; DOS ANJOS, L. H. C. Modelos de elevação para obtenção de atributos topográficos utilizados em mapeamento digital de solos. Pesquisa Agropecuária Brasileira, v. 47, n. 9, p. 13841394, 2012.

PRATES, V.; SOUZA, L. C. D. P.; OLIVEIRA JUNIOR, J. C. D. Índices para a representação da paisagem como apoio para levantamento pedológico em ambiente de geoprocessamento. Revista Brasileira de Engenharia Agrícola e Ambiental, v. 16, n. 4, p. 408-414, 2012.

REIS, D. A.; LIMA, C. L. R.; PAULETTO, E. A. Resistência tênsil de agregados e compressibilidade de um solo construído com plantas de cobertura em área de mineração de carvão em Candiota, RS. Revista Brasileira de Ciência do Solo, v. 38, p. 669-78, 2014.

SALAMENE, S.; FRANCELINO, M. R.; VALCARCEL, R.; LANI, J. L.; SÁ, M. M. F. Estratificação e caracterização ambiental da área de preservação permanente do Rio Guandu/RJ. Revista Árvore, v. 35, n. 2, p. 221-231, 2011.

SANTOS, H. D.; JACOMINE, P. K. T.; ANJOS, L. D.; OLIVEIRA, V. D.; OLIVEIRA, J. D.; COELHO, M. R.; CUNHA, T. D. Sistema brasileiro de classificação de solos. 3. ed. Rio de Janeiro: Embrapa Solos, 2013.

TACCONI, L. Redefining payments for environmental services. Ecological Economics, v. 73, p. 29-36, 2012. https://doi.org/10.1016/j.ecolecon.2011.09.028

VALERIANO, M. D. M. Curvatura vertical de vertentes em microbacias pela análise de modelos digitais de elevação. Revista Brasileira de Engenharia Agrícola e Ambiental, v. 7, n. 3, p. 539-546, 2003.

WILSON, J. P.; GALLANT, J. C. Digital terrain analysis. In: WILSON, J. P.; GALLANT, J. C. (Eds.). Terrain analysis: Principles and applications. New York: Wiley, 2000. p. 127. 